\title{
Informatics Education in Italian Secondary Schools
}

\author{
CARLO BELLETTINI, VIOLETTA LONATI, DARIO MALCHIODI, MATTIA MONGA, \\ ANNA MORPURGO, and MAURO TORELLI, Università degli Studi di Milano \\ LUISA ZECCA, Università degli Studi di Milano-Bicocca
}

\begin{abstract}
This article describes the state of informatics education in the Italian secondary schools, highlighting how the learning objectives set up by the Ministry of Education are difficult to meet, due to the fact that the subject is often taught by teachers not holding an informatics degree, the lack of suitable teaching material and the expectations of pupils and families, who tend to identify informatics with the use of computer applications.
\end{abstract}

Categories and Subject Descriptors: K.3.2 [Computers and Education]: Computer and Information Science Education-Computer science education

General Terms: Human Factors

Additional Key Words and Phrases: Informatics education, secondary school

ACM Reference Format:

Bellettini, C., Lonati, V., Malchiodi, D., Monga, M., Morpurgo, A., Torelli, M., and Zecca, L. 2014. Informatics education in Italian secondary school. ACM Trans. Comput. Educ. 14, 2, Article 15 (June 2014), 6 pages.

DOI : http://dx.doi.org/10.1145/2602490

\section{MOTIVATION}

Several researchers have noted how a number of cultural approaches merge in the term informatics (which we prefer to the more common terms computing and computer science). For example, Mirolo [2003] distinguishes: (1) informatics as a science, providing its own peculiar key to interpret reality and its specific approach to problem solving; (2) informatics as a technology, concerning the characteristics, structure and working principles of the now ubiquitous hardware and software devices; (3) informatics as an instrument, providing practical tools in many different contexts.

Some widespread initiatives have put most of the emphasis on the instrumental approach: for example, the European Computer Driving Licence (ECDL) initiative has been typically focused on this aspect and it has had great popularity in Italian secondary schools. Indeed, in the last two decades, in Italy most of the informatics education not explicitly directed to the forthcoming experts of the field was aimed at achieving a generic digital literacy.

However, we believe that the contribution informatics can give to education is much broader. Moreover, a recent UK report [Royal Society 2012] gives several pieces of evidence on how an approach mainly focused on the instrumental value of Information and Communication Technologies (ICTs) failed to lead pupils and teachers to develop any real understanding in computing. Besides, [CSTA Curriculum Improvement Task Force 2005] clearly identifies that there is an incorrect public image of the discipline

Authors' addresses: C. Bellettini, V. Lonati, D. Malchiodi, M. Monga (corresponding author), and A. Morpurgo, M. Torelli, Dipartimento di Informatica, Università degli Studi di Milano; email: mattia.monga@unimi.it; L. Zecca, Dipartimento di Scienze Umane per la Formazione, Università degli Studi di Milano-Bicocca.

Permission to make digital or hard copies of all or part of this work for personal or classroom use is granted without fee provided that copies are not made or distributed for profit or commercial advantage and that copies bear this notice and the full citation on the first page. Copyrights for components of this work owned by others than ACM must be honored. Abstracting with credit is permitted. To copy otherwise, or republish, to post on servers or to redistribute to lists, requires prior specific permission and/or a fee. Request permissions from permissions@acm.org.

(C) 2014 ACM 1946-6226/2014/06-ART15 $\$ 15.00$

DOI : http://dx.doi.org/10.1145/2602490 
among outsiders, but also among "students, prospective teachers, in-service teachers, and others involved in computer science education." In Italy the situation is not different: even if a recent reform of secondary schools (described in Section 2) introduced, among the learning objectives, several topics clearly oriented to the scientific and technological sides of informatics, the state of the actual teaching is still predominantly focused on applications. We identified some critical points: (1) teachers responsible for teaching informatics do not necessarily hold a degree in informatics or computer science related field (see Section 2); (2) there are no consolidated practices for informatics education, especially for classes where this subject has been introduced only recently; (3) the available textbooks typically focus on technological and instrumental aspects; (4) teachers are put under pressure from parents and media about short-term digital literacy, rather than on long-term understanding of computing issues.

The next section describes the state of informatics education in the Italian secondary schools as designed by the recent reform, while Section 3 presents some final remarks.

\section{INFORMATICS IN ITALIAN SECONDARY SCHOOLS}

The secondary school system in Italy is organized on two levels: (1) Lower secondary education, ${ }^{1}$ grades 6 th to 8 th (pupils aged 11-13); (2) Upper secondary education, ${ }^{2}$ grades 9th to 13th (pupils aged 14-18). Between 1997 and 2010 it was repeatedly reformed $^{3}$ in many aspects. These reforms were mainly aimed at simplifying and harmonizing the structure of the whole educational system [Briguglio 2011].

Schooling is compulsory for ten years, thus pupils normally have to attend school until the age of 16 (grade 10th). The Ministry of Education establishes curricula and learning objectives centrally, but schools have a form of autonomy in their implementations. Teacher qualification for accessing the profession is also under revision: the planned idea is to have teachers with a bachelor's degree in the discipline and a twoyear master in discipline teaching. Such courses have not been activated yet, however. Recently, a transitional regime started, during which people who hold a master's degree may attend a one-year qualification course, called "Tirocinio Formativo Attivo" (TFA). Both before the reform and now, the key requirement for teaching in secondary schools is a master's degree. Anyway, the mapping between specific degrees and taught subjects is very complex: the current situation can be checked through a Web application ${ }^{4}$ published by the Ministry of Education.

\subsection{Lower Secondary Education}

The lower secondary education (503,933 pupils $^{5}$ ) level is planned over three years, with pupils attending school 30-40 hours per week for 33 weeks. Informatics is not a subject taught by itself, but pupils attend 6-9 hours per week of "Maths and Science" and two hours of "Technology" in which informatics should be introduced: the law [DL59 2004] mandates that the lower secondary school shall "organize and augment skills and knowledge about contemporary society also through ICT."

Qualification of Maths and Science or Technology teachers varies a lot: Math and Science can be taught by instructors with a master's degree in Mathematics, Astronomy, Chemistry, Physics, Biology and other natural sciences (but not Informatics); Technology can be taught by instructors with a master's degree in Architecture, Urban

\footnotetext{
${ }^{1}$ Italian name: Scuola secondaria di primo grado.

${ }^{2}$ Italian name: Scuola secondaria di secondo grado.

${ }^{3}$ For a survey of informatics education in Italy before the reform see Cartelli [2002].

${ }^{4} \mathrm{http}$ //hubmiur.pubblica.istruzione.it/PRTA-TitoliAccesso/avvio.action, in Italian.

${ }^{5}$ All the figures refer to the year 2013 subscriptions to the initial grade [MIUR 2013a, 2013b].
} 
Planning, Industrial Chemistry, Engineering and other technology oriented degrees (but not Informatics). As a result, teachers with a formal education in informatics are rare, since this is not required, and the exposure of pupils to informatics in most cases is minimal or limited to the use of office productivity tools.

\subsection{Upper Secondary Education}

The upper secondary education (515,807 pupils), generally planned over five years, is rather diversified and dozens of different schools exist. However, the main distinction is among three kinds of education:

- Lyceum (253,091 pupils), aimed at a general education typically refined with further tertiary studies and available with different main focuses ${ }^{6}$ : Classical (31,591), Scientific (117,439), Linguistic (43,172), Artistic (20,823), Music (2,956), Human Sciences $(34,611)$;

- Technical schools (161,873 pupils), vocational education with two main orientations $^{7}$ : Economics $(65,919)$ and Technology $(95,954) ;$

- Professional schools (93,641 pupils), vocational education with two main orientations $^{8}$ : Services $(25,484)$ and Manufacturing $(68,157)$.

The Ministry of Education has published some guidelines describing learning objectives and the profile of successful students. In discussing the role of informatics we refer to them, even if the implementation in schools is not complete yet.

2.2.1. Lyceum. As an independent subject, Informatics is planned only in a special curriculum of the Scientific Lyceum, focused on Applied Sciences (32,431 pupils). However, for all the Lyceum schools in the first two years Mathematics should also include "Elements of informatics" according to the guide [DPR89 2010].

the student shall familiarize with software tools with the explicit goal of managing mathematical entities and he or she shall study the techniques to represent text and multimedia data. A fundamental topic shall be the concept of algorithm and algorithmic strategies to solve simple problems for which simple models exist; moreover he or she shall study the concepts of computable function, decidability and related simple examples.

In the Applied Sciences Scientific Lyceum, Informatics has two hours per week during all the five years. The lessons should include most of the main topics of the discipline: hardware architectures, operating systems, algorithms and programming languages, computer networks, databases, numerical simulations. However, all the post-reform textbooks we analyzed focus on ICT tools and introduce just a bit of programming, and in some cases also cover query and mark-up languages.

As far as teacher qualification is concerned: in the Lyceum Mathematics can be taught by instructors with a master's degree in Mathematics, Physics, Informatics, Statistics, or Engineering; Informatics can be taught by instructors with a master's degree in Informatics, Physics, Mathematics, some Engineering (Information, Industrial, Telecommunication, Electronics, Aerospatial).

2.2.2. Technical Schools. Technical schools provide vocational education to pupils eager to work in administrative or technological areas.

\footnotetext{
${ }^{6} \mathrm{http}: / /$ nuovilicei.indire.it/, in Italian.

${ }^{7} \mathrm{http}: / /$ nuovitecnici.indire.it/, in Italian.

${ }^{8} \mathrm{http}: / /$ nuoviprofessionali.indire.it/, in Italian.
} 
Technical school in the sector of Economics. For the administrative area the main emphasis is on the potentialities of ICT as a means to reorganize firms. Informatics has two hours per week for the first four years. Besides, there is a special course in Information Systems, which has four hours in the third year and five hours in the fourth and fifth years. Informatics should provide knowledge about: information, data, and codification; computer architecture; human-computer communication; structure and functionalities of an operating system; software tools and Enterprise Resource Planning; problems, algorithms and their representation; data organization; fundamentals of programming; structure of a computer network; Internet and email; privacy and copyright issues. Such course should help students

use networks and software tools for their study activities; choose and exploit modern forms of visual and multimedia communication, also with a reference to their use in networks; master technological tools with a special attention to safety and environmental friendliness; operate in the information system of a firm and contribute to its organizational and technological innovation; effectively elaborate, interpret, and represent business data with software tools; analyze social and business phenomena with mathematical and software tools. [DPR89:tech 2010]

Technical school in the sector of Technology. In this area there is a specific curriculum on Informatics, with several courses in which the discipline is taught: Technology of Informatics (three hours per week in the 1st year), Science and Applied Technology (three hours per week in the 2nd year), Informatics (six hours per week from the 3rd year to the 5th), Systems and Networks (four hours per week from the 3rd year to the 5th), Technology and System Design (three hours per week from the 3rd year to the 4 th, four hours per week in the 5th), Project management (three hours per week in the 5th year). The other curricula only have the Technology of Informatics course in the 1st year ${ }^{9}$. Technology of Informatics should provide knowledge about: information, data, and codification; computer architecture; human-computer communication; functionalities of an operating system; software tools and applications; problem solving and representation; fundamentals of programming; structure of a computer network; Internet networking; privacy and copyright issues. Students should learn to:

use networks and software tools for their study activities; use procedures and techniques to find innovative solutions in applied research contexts; use methodological and cultural tools to face phenomena and problems of the real world with a rational and critical approach. [DPR89:tech 2010]

2.2.3. Professional Schools. Informatics is taught in two courses titled "Technologies for information and communication" and "Informatics and laboratory" (two hours per week in the 1st and 2nd year). The high level objectives are very instrumental to the main disciplines of the curriculum, but the knowledge to be proposed in the courses is defined in terms analogous to the courses taught in the Technical schools.

2.2.4. Teacher Qualification. Teachers must hold a master's degree in order to teach in any upper secondary school. Moreover, in Italy in order to obtain a permanent public job, candidates have to participate to a competitive exam. There exists a specific section for Informatics, open to people with a degree in Informatics, Physics, Mathematics, Information Engineering, Electronic Engineering, Telecommunication Engineering, Industrial Engineering, Aerospatial Engineering, Nautical Sciences.

\footnotetext{
${ }^{9}$ There are two exceptions: the Telecommunication curriculum, in which Informatics only takes three hours per week, and the Graphics curriculum that adds the Science and Applied Technology one.
} 


\section{FINAL REMARKS AND CHALLENGES}

Although, according to a recent reform, informatics should be taught within several curricula in the Italian secondary schools, according to our contacts with teachers and classes the learning objectives described in the previous section are far from being met. Our impression is that such a situation is common in the whole secondary school system. As a result, the power of informatics is often hindered by a predominant focus on using computer applications and the discipline risks to be perceived as a bag of ready-to-use recipes, with almost no space for creativity, understanding and cleverness.

In order to experiment with a different approach, we started designing and implementing special enrichment programs (see the website of our laboratory: http:// aladdin.di.unimi.it) to introduce pupils to the topics of information representation and algorithmics [Bellettini et al. 2012, 2013; Lonati et al. 2011], taking inspiration from [Bell et al. 2012; Pattis 1981]. Our goal was to present abstract symbolic manipulations in a very concrete way, but without starting from computers. Computers come at the end, just to close the conceptual loop with the previous acquaintance of the pupils with the ubiquitous ICT tools. We had the opportunity to test such activities in a lower-level and in an upper-level secondary school. As a result, we could prepare a set of two-hour workshops which were held to classes of 20-25 pupils, for a total of 26 classes during 2013 (the activities are ongoing, with 26 workshops currently planned in 2014). Our intention was twofold: (i) to propose a methodological approach to informatics teachers, and (ii) to present some core aspects of informatics to both pupils and teachers. The feedback we received was very positive, both from pupils and teachers. Although an extensive evaluation and assessment of the workshops has not been done yet, we can say that all classes participated with engagement in the proposed activities, collaborating, discussing different points of view, and showing satisfaction for their achievements. Many pupils admitted that their idea of informatics and of the job of ICT professionals changed after they had attended the workshop. Thus, we believe our workshops could represent a valuable experience to support teachers, and we want to use them as a starting point for further action research.

\section{REFERENCES}

Tim Bell, Frances Rosamond, and Nancy Casey. 2012. Computer science unplugged and related projects in math and computer science popularization. In The Multivariate Algorithmic Revolution and Beyond, Hans L. Bodlaender, Rod Downey, Fedor V. Fomin, and Dániel Marx, Eds., Springer, 398-456.

Carlo Bellettini, Violetta Lonati, Dario Malchiodi, Mattia Monga, Anna Morpurgo, and Mauro Torelli. 2012. Exploring the processing of formatted texts by a kynesthetic approach. In Proceedings of the 7th Workshop in Primary and Secondary Computing Education (WiPSCE '12). ACM, New York, 143-144.

Carlo Bellettini, Violetta Lonati, Dario Malchiodi, Mattia Monga, Anna Morpurgo, and Mauro Torelli. 2013. What you see is what you have in mind: Constructing mental models for formatted text processing. In Proceedings of the International Conference on Informatics in Schools (ISSEP '13). I. Diethelm, J. Arndt, M. Dünnebier, and J. Syrbe, Eds., Vol. 6, Universitätsverlag Postdam, Universität Potsdam, 139-147.

Anna E. Briguglio. 2011. Dal ministero Berlinguer alla riforma Gelmini: note cursorie per riflettere sugli itinerari della formazione e dell'istruzione in Italia. Quaderni di Intercultura 3, 1-25.

Antonio Cartelli. 2002. Computer science education in Italy: A survey. SIGCSE Bull. 34, 4, 36-39.

CSTA Curriculum Improvement Task Force. 2005. The new educational imperative: Improving high school computer science education. Tech. Rep., Computer Science Teachers Association. http://csta.acm.org/Communications/sub/DocsPresentationFiles/White_Paper07_06.pdf.

DL59. 2004. Definizione delle norme generali relative alla scuola dell'infanzia e al primo ciclo dell'istruzione, a norma dell'art. 1 della legge 28/3/2003, n. 53 . http://archivio.pubblica.istruzione.it/riforma/allegati/dl190204.pdf.

DPR89. 2010. Indicazioni nazionali riguardanti gli obiettivi specifici di apprendimento concernenti le attività e gli insegnamenti compresi nei piani degli studi previsti per i percorsi liceali di cui all'art. 10 , comma 3, del DPR 15/3/2010, n. 89, in relazione all'art. 2, commi 1 e 3, del medesimo regolamento. 
http://www.indire.it/lucabas/lkmw_file/licei2010///indicazioni_nuovo_impaginato/_decreto_indicazioni nazionali.pdf.

DPR89: tech. 2010. Istituti tecnici, linee guida per il passaggio al nuovo ordinamento.

http://www.indire.it/lucabas/lkmw_file/nuovi_tecnici///INDIC/LINEE_GUIDA_TECNICI_.pdf.

Violetta Lonati, Mattia Monga, Anna Morpurgo, and Mauro Torelli. 2011. What's the fun in informatics? Working to capture children and teachers into the pleasure of computing. In Informatics in Schools, I. Kalás and R. T. Mittermeir Eds., Lecture Notes in Computer Science, vol. 7013, Springer, 213-224.

Claudio Mirolo. 2003. Quale informatica nella scuola? http://nid.dimi.uniud.it/pages/materials/discussion/educazione.pdf. (2003).

MIUR. 2013a. Comunicato stampa: Scuola, i risultati delle iscrizioni alle prime classi degli istituti superiori. http://hubmiur.pubblica.istruzione.it/web/ministero/cs250313bis.

MIUR. 2013b. Comunicato stampa: Scuola, si chiudono con successo le iscrizioni on line. http://hubmiur.pubblica.istruzione.it/alfresco/d/d/workspace/SpacesStore/c0331996-3052-472e-81a4c09474191a9a/cs010313.pdf.

Richard E. Pattis. 1981. Karel the Robot: A Gentle Introduction to the Art of Programming 1st Ed. John Wiley \& Sons, Inc., New York.

Royal Society. 2012. Shut down or restart? The way forward for computing in UK schools. http://royalsociety.org/education/policy/computing-in-schools/report/.

Received March 2013; revised July 2013, January 2014, March 2014; accepted April 2014 